\title{
CHARACTERISATION OF MORINGA OLEIFERA (DRUMSTICK) WOOD FOR PULP AND PAPER MAKING
}

\author{
ARVIND SHARMA, GUNJAN DHIMAN, PRITI S. LAL, RAVI D. GODIYAL and \\ BIPIN P. THAPLIYAL \\ Central Pulp and Paper Research Institute, Himmat Nagar, Saharanpur 247001, \\ Uttar Pradesh, India \\ Corresponding author: Arvind Sharma, arvind17sharma@yahoo.com
}

Received May 3, 2020

\begin{abstract}
Moringa oleifera (drumstick) wood was evaluated in terms of its chemical composition, morphological features, Kraft pulping behavior, ECF bleaching and mechanical strength properties - important parameters for pulp and paper making - in comparison with Acacia mangium. Moringa oleifera was found to have the following composition: holocellulose $65.5 \%$, lignin $20.5 \%$, pentosan $11.6 \%$, $\alpha$-cellulose $40.5 \%$ and extractives content of $5.15 \%$, which made it comparable with the Acacia mangium wood sample. The alkali prehydrolysis of Moringa oleifera was carried out using $2 \% \mathrm{NaOH}$ at $150{ }^{\circ} \mathrm{C}$. The prehydrolysis liquor (PHL) was found to contain $50.9 \mathrm{mg} / \mathrm{kg}$ of calcium, $5140 \mathrm{mg} / \mathrm{kg}$ of potassium and $312 \mathrm{mg} / \mathrm{kg}$ of iron content. The prehydrolysis step was followed by Kraft pulping in order to obtain chemical grade pulp of kappa number 15-16 under optimized conditions. The Moringa oleifera pulp was bleached using the DEpD bleaching sequence to reach $85 \%$ brightness (ISO). The bleached pulp had an average fiber length of $1.21 \mathrm{~mm}$, which was higher than that of Acacia mangium - $0.782 \mathrm{~mm}$. The mechanical strength properties of the unbleached and bleached pulps, such as tear, tensile and burst indices, were also determined to show their suitability for pulp and paper production.
\end{abstract}

Keywords: proximate chemical analysis, morphology, alkali prehydrolysis, Kraft pulping, bleaching, mechanical strength properties

\section{INTRODUCTION}

Shortages of forest resources are forcing the Indian pulp and paper industry to turn towards other raw materials for pulp and paper making. To solve this problem, wood-based pulp and paper mills have initiated agro-forestry or farm forestry schemes, allowing the use of various alternative fibrous resources, such as non-wood plants and agricultural residues, as feedstock. It has been estimated that, due to agro-forestry plantations, $46 \%$ of global agricultural land is more than $10 \%$ covered by trees. ${ }^{1}$ The growing demand of wood has motivated the establishment of short rotation forest plantations in developing and developed countries. $^{2}$ Moringa oleifera (drumstick) wood has been identified as a potential hardwood for pulp and paper production. India is the largest producer, with an annual production of 1.2 million tonnes of fruits, from an area of $380 \mathrm{~km}^{2}$.

Moringa oleifera tree is a member of the Moringaceae family, it is a single genus family with 14 moringa species. ${ }^{4}$ Moringa oleifera is a small, fast-growing, tropical, drought resistant deciduous tree/shrub. ${ }^{5}$ It can be planted by seeds or stem cuttings. It has its origin in Arabia and India, where it has multiple uses. Moringa oleifera can tolerate a wide range of environmental conditions. It can resist light frost, and though its best growth is observed between $25{ }^{\circ} \mathrm{C}$ and $35^{\circ} \mathrm{C}$, it can tolerate up to $48^{\circ} \mathrm{C}$ under the shade.

The numerous economic uses of Moringa oleifera, together with its ease of propagation, have raised interest nationwide and internationally for utilization of this tree. Agronomic trails with Moringa oleifera show that the plant can grow well in hilly areas, as well as in weathered soils of low fertility. ${ }^{6}$ The multiple uses of Moringa oleifera include alley farming, biopesticides, pulp (wood), bark, tannin for tanning hides (bark and gum), water purification, medicine, animal forage, ornamental plantings and domestic cleaning agent. All parts of the plant are used in traditional 
medicine. The press cake, obtained after oil extraction, is useful as a soil conditioner. The plants are grown as live fences and windbreaks. It is also a source of fuel wood after coppicing (cutting the main stem to encourage side shoots), as an intercrop with other crops, its wood pulp may be used for paper making. The green pods and fresh and dried leaves are used as vegetable.

Much research has been done on the nutritional qualities of Moringa oleifera, as well as on its uses for water purification, soil fertility, medicine for various ailments, oil, animal feed and biopesticides. However, scarce studies are known to have investigated its physical and chemical properties to ascertain its suitability for pulp and paper making. ${ }^{7}$ In the present study, Moringa oleifera was evaluated with regard to its chemical composition, morphological characteristics, behavior during prehydrolysis, followed by kraft pulping, elemental chlorine free (ECF) bleaching. It was found that kraft pulping at an optimized freeness from 350 to $400 \mathrm{~mL}$ (CSF) yielded fibers with optimum mechanical strength. The main driving force for this work has been to identify an alternative wood raw material for the wood based pulp and paper industry.

\section{EXPERMENTIAL}

\section{Materials and methods}

The Moringa oleifera sample was collected from a home garden in Delhi, and chipped in a laboratory disc chipper. The chip samples were mixed thoroughly and kept in polythene bags to attain uniform moisture. The moisture content of the chip samples was determined as per standard procedures prior to pulping experiments. To determine the chemical composition of Moringa oleifera, the chip sample was milled to powder in a laboratory Wiley Mill (Thomas) as per Tappi T $257 \mathrm{sp}-14$, and the fraction passing through the 40 mesh size, but retained on +80 mesh size, was collected in polythene bags.

The chemical composition was determined according to the respective standard procedures, as follows: alpha, beta and gamma cellulose (TAPPI-203 cm-99), holocellulose content by Wise's chloride method (Wise, 1946), acid insoluble lignin (TAPPI T 222 om-02), pentosan ( T $223 \mathrm{~cm}-84$ ), ash content (TAPPI-211 om-02); cold and hot water solubility (TAPPI-207 cm-99), 0.1N NaOH solubility (APPITA P 5M 61), alcohol benzene solubility (TAPPI T 204 cm-97).

\section{Alkali prehydrolysis}

The alkali prehydrolysis of the Moringa oleifera sample was carried out in a laboratory series digester, with $2 \% \mathrm{NaOH}$ and a wood to water ratio of 1:5, temperature of $150{ }^{\circ} \mathrm{C}$ for 60 minutes. The alkali prehydrolysis liquor was removed from the chips and collected on teryelene cloth. The alkali prehydrolysed chips were further used for kraft pulping experiments.

\section{Mineral estimation}

The untreated Moringa oleifera wood dust sample and the alkali prehydrolysis liquor (PHL) were analyzed in terms of their contents of minerals, such as $\mathrm{Fe}, \mathrm{Si}, \mathrm{Ca}, \mathrm{Mg}, \mathrm{K}, \mathrm{P}, \mathrm{Na}, \mathrm{Al}$ and $\mathrm{Co}$, by Inductively Coupled Plasma Optical Emission Spectroscopy (ICPOES).

\section{Kraft pulping}

The kraft pulping was carried out in a laboratory series digester, consisting of six bombs (Stalsvets, Alfa Aval Group, Sweden), each of $2.5 \mathrm{~L}$ capacity, rotating in an electrically heated polyethylene glycol bath. The kraft pulping experiments were carried out using different cooking chemical doses: 16,18 and $20 \%$ as $\mathrm{Na}_{2} \mathrm{O}$, in order to produce chemical grade pulp of kappa number 15-16, using the following pulping conditions: 1:3.5 solid to liquid ratio (SLR) and 90 min time, sulphidity $20 \%$. At the end of the pulping, the material obtained was dispersed with a pulp disintegrator, and washed with hot water to remove the black liquor and dissolved substances. Subsequently, the pulp was screened on a laboratory Somerville vibratory screen, using the mesh of $0.15 \mathrm{~mm}$ slot size to separate reject as per Tappi T275sp12 before the bleaching of pulp. The unbleached pulps were then analysed in terms of kappa number (TAPPI T 236 om-06), brightness (ISO 2471), viscosity (SCAN C 15:65) and freeness (ISO DP 5269).

\section{Bleaching}

The elemental chlorine free (ECF) bleaching of Moringa oleifera pulps was carried out in the laboratory by the $\mathrm{D}_{0} \mathrm{E}_{\mathrm{P}} \mathrm{D}_{1}$ bleaching sequence to achieve pulp brightness of $\sim 85 \%$ (ISO). During bleaching experiments, the consistency, temperature, time and $\mathrm{pH}$ were maintained in $\mathrm{D}_{0}, \mathrm{Ep}$ and $\mathrm{D}_{1}$ bleaching stages as follows: $5.0 \%, 70{ }^{\circ} \mathrm{C}, 45 \mathrm{~min}$ and $\mathrm{pH} 2-3 ; 10.0 \%, 65 \pm 5$ ${ }^{\circ} \mathrm{C}$, 60 min and inlet $\mathrm{pH} 11-12 ; 10.0 \%, 80{ }^{\circ} \mathrm{C}, 180 \mathrm{~min}$ and inlet $\mathrm{pH} 3-4$, respectively. Polythene bags and a hot water bath (Julabo TW 20, Germany) were used for bleaching experiments. The pulps were thoroughly washed in a Buchner funnel vacuum pump with tap water after each stage of the bleaching sequence. The $\mathrm{pH}$ of the pulp was maintained by adding $\mathrm{H}_{2} \mathrm{SO}_{4}$ in the $\mathrm{D}_{0}$ and $\mathrm{D}_{1}$ bleaching stages. The bleached pulp characteristics, such as kappa number, brightness, viscosity and yield, were measured by standard methods.

\section{Fiber morphology}

Detailed morphological features, such as fiber length, fiber width, curl and kink index of the bleached pulp, were evaluated using a Hi-Resolution Fiber Quality Analyser (Optest Equipment Inc., model: LDA 2002). All the other characteristics, such as cell wall thickness, 
lumen diameter, length of parenchyma and length of vessel, were determined using a projection microscope. The following parameters were calculated for the fibers: ${ }^{8}$ Slenderness ratio $=$ fiber length/fiber diameter; Flexibility coefficient $=100 \times$ (fiber lumen diameter)/(fiber diameter); Runkel ratio $=2 x$ (fiber cell wall thickness $) /($ lumen diameter); Rigidity coefficient $=$ $100 \times$ /cell wall thickness)/fiber diameter).

\section{Mechanical strength properties}

The unbleached and bleached Moringa oleifera pulps were refined in a laboratory PFI mill (T 200 sp-96) at different beating levels. Handsheets of $60 \mathrm{gsm}$ were prepared from unbleached and bleached pulps, on a British sheet former machine. The handsheets were pressed, air dried in atmospheric conditions at $27 \pm 1{ }^{\circ} \mathrm{C}$ and relative humidity of $65 \pm 2{ }^{\circ} \mathrm{C}$, and tested for various physical properties according to the ISO 5269.1:2005 standard to measure apparent density (ISO 534:1988E), burst index (ISO 2758), tensile index (ISO 1924), tear index (ISO 1974) and double fold (T403 om-97).

\section{RESULTS AND DISCUSSION \\ Proximate chemical analysis}

According to the results of proximate chemical analysis tabulated in Table 1, the amount of holocellulose indicates a total carbohydrate content of $65.5 \%$, which is a promising value, only slightly lower than that of Acacia mangium of $72 \% .^{9}$ Some researchers have reported corresponding values of $68.5 \%$ and $73.31 \%$, respectively. ${ }^{10}$ The holocellulose content indicates that, with milder pulping conditions, the pulp yield could be significantly improved. The acid insoluble lignin is $6.59 \%$ lower than that of the Acacia wood sample. The lignin content influences the pulping time and the chemical charge; thus, high lignin content corresponds to a longer pulping time and a higher chemical charge. The ash content was $70.8 \%$ higher compared to that of the other hardwood sample. Higher ash corresponds to more minerals in the pulp. The content of high molecular weight carbohydrates, i.e. á-cellulose, is $5.20 \%$ lower than in Acacia mangium. The pentosan content is slightly lower in the case of Moringa oleifera, compared to Acacia mangium. The amount of pentosan also reveals the presence of hemicelluloses in the raw material. The hemicelluloses help in retaining the strength of a ligno-cellulosic raw material.

\section{Alkali prehydrolysis followed by kraft pulping}

Table 2 shows the results of alkali prehydrolysis and kraft pulping optimization for unbleached Moringa oleifera pulp. The carbohydrate content in the raw material pulp is represented by the yield of pulp and it is slightly lower in Moringa oleifera, compared to the Acacia sample. After alkali prehydrolysis of the chips, the optimum active chemical demand is of $20 \% \mathrm{Na}_{2} \mathrm{O}$, to reach the target kappa number (16.2). The screened yield, viscosity and brightness of the unbleached Moringa oleifera pulp were of $38.2 \%, 772 \mathrm{cc} / \mathrm{g}$ and $29.5 \%$, respectively.

\section{Elemental analysis of samples}

The findings of elemental analysis performed on Moringa oleifera wood and alkali prehydrolysis liquor (PHL) samples are given in Table 3. The alkali prehydrolysis liquor shows the presence of some useful ingredients, which may be further valorized in many ways. The possibility to turn it into value added products needs to be analysed. Alkali prehydrolysis degrades the low molecular weight carbohydrates, along with the minerals from the materials. In this study, the alkali prehydrolysis liquor contains $50.9 \mathrm{mg} / \mathrm{kg}$ calcium, $5140 \mathrm{mg} / \mathrm{kg}$ potassium and $312 \mathrm{mg} / \mathrm{kg}$ iron content (Table 3).

Table 1

Proximate chemical analysis of Moringa oleifera in comparison with Acacia mangium raw materials

\begin{tabular}{lcc}
\hline Parameter & Moringa oleifera & Acacia mangium \\
\hline Cold water solubility & $6.6 \%$ & $1.23 \%$ \\
Hot water solubility & $16.1 \%$ & $3.24 \%$ \\
$1 / 10 \mathrm{~N}$ NaOH solubility & $20.7 \%$ & $17.3 \%$ \\
Alcohol benzene solubility & $3.16 \%$ & $1.78 \%$ \\
Ash content & $3.5 \%$ & $1.9 \%$ \\
Acid insoluble lignin content & $24.1 \%$ & $25.8 \%$ \\
Holocellulose (ash and lignin corrected) & $65.5 \%$ & $72.0 \%$ \\
Pentosan content & $12.4 \%$ & $14.5 \%$ \\
á-Cellulose content & $38.9 \%$ & $42.3 \%$ \\
\hline
\end{tabular}


Table 2

Conditions for alkali prehydrolysis and optimization of kraft cooking chemical dose

\begin{tabular}{|c|c|c|c|}
\hline \multirow{2}{*}{$\begin{array}{l}\text { Parameters } \\
\text { Alkali prehydrolysis stage }\end{array}$} & \multicolumn{3}{|c|}{ Value } \\
\hline & & & \\
\hline Alkali applied, $(\% \mathrm{NaOH})$ & 2.0 & 2.0 & 2.0 \\
\hline Bath ratio & 1.3 .5 & $1: 3.5$ & $1: 3.5$ \\
\hline \multicolumn{4}{|l|}{ Cooking stage } \\
\hline Alkali applied, $\left(\% \mathrm{Na}_{2} \mathrm{O}\right)$ & 16.0 & 18.0 & 20.0 \\
\hline Sulphidity & 20 & 20 & 20 \\
\hline Unscreened pulp yield, $\%$ & 40.5 & 39.1 & 38.2 \\
\hline Rejects, \% & 0.21 & 0.1 & nil \\
\hline Screened yield, \% & 40.29 & 38.9 & 38.2 \\
\hline Kappa number & 21.7 & 19.0 & 16.2 \\
\hline Brightness, \% (ISO) & 25.4 & 27.3 & 29.5 \\
\hline Viscosity, cc/g & 823 & 801 & 772 \\
\hline Freeness $\mathrm{mL}, \mathrm{CSF}$ & - & - & 650 \\
\hline \multicolumn{4}{|l|}{ Constant cooking conditions: } \\
\hline \multicolumn{4}{|l|}{ Alkali prehydrolysis stage } \\
\hline Ambient to $150{ }^{\circ} \mathrm{C}$ & & $30 \mathrm{~min}$ & \\
\hline At $150^{\circ} \mathrm{C}$ & & $60 \mathrm{~min}$ & \\
\hline \multicolumn{4}{|l|}{ Cooking stage } \\
\hline Ambient to $100^{\circ} \mathrm{C}$ & & $30 \mathrm{~min}$ & \\
\hline $100{ }^{\circ} \mathrm{C}$ to $160^{\circ} \mathrm{C}$ & & $60 \mathrm{~min}$ & \\
\hline At $160^{\circ} \mathrm{C}$ & & $90 \mathrm{~min}$ & \\
\hline
\end{tabular}

Table 3

Elemental analysis of Moringa oleifera wood and alkali prehydrolysis liquor

\begin{tabular}{lcc}
\hline Elements & $\begin{array}{c}\text { Moringa oleifera } \text { wood } \\
\text { sample, } \mathrm{mg} / \mathrm{kg}\end{array}$ & $\begin{array}{c}\text { Alkali prehydrolysis } \\
\text { liquor sample, } \mathrm{mg} / \mathrm{kg}\end{array}$ \\
\hline $\mathrm{Fe}$ & 1270 & 312 \\
$\mathrm{Si}$ & 97.0 & 32.2 \\
$\mathrm{Ca}$ & 56.0 & 50.9 \\
$\mathrm{Mg}$ & 3806 & 97.4 \\
$\mathrm{~K}$ & 7587 & 5140 \\
$\mathrm{P}$ & 44.6 & 3.84 \\
$\mathrm{Na}$ & 1577 & 61.0 \\
$\mathrm{Al}$ & - & 50.0 \\
$\mathrm{Co}$ & 18.4 & 4.32 \\
\hline
\end{tabular}

\section{Morphological features of Moringa oleifera pulps}

Table 4 shows the morphological features of Moringa oleifera pulp - like all hardwood pulps, it exhibits a greater diversity of cell types than softwood pulps. Individual fibers measure 0.35 to $3.12 \mathrm{~mm}$ (average $1.21 \mathrm{~mm})$ in length, $(15.0 \mu \mathrm{m})$ in width, average cell wall thickness of $3.11 \mu \mathrm{m}$, with an average lumen diameter of $8.78 \mu \mathrm{m}$. The fibers have a relatively broad middle region, smooth wall and abrupt to gradual tapering pointed ends, which are sometimes separated. Fiber length affects the tearing strength of paper. The greater the length of the fiber, the higher the tearing strength of paper will be. The fibers of Moringa oleifera are wider and thin-walled, compared to Acacia mangium. Thin-walled fibers affect positively the bursting strength, tensile strength and double fold number of paper. Wider fiber lumen gives better pulp fibrillation in a shorter period of time due to easier penetration of liquids into the fiber lumen.

Six associated parameters were calculated using the determined fiber dimensions to assess the suitability of the moringa fiber for paper making: Runkel ratio, Luce's shape factor, slenderness ratio, solid factor, felting power and flexibility coefficient. ${ }^{11}$ The values were then compared to those of other hardwoods to assess the effect of the derived values on various pulp and paper making characteristics. 
The slenderness ratio (L/D) is also known as felting power; the slenderness ratio of individual fibers affects their flexibility and resistance to rupture, as well as the degree of fiber bonding within the fiber matrix. The fibers of Moringa oleifera offer a higher degree of collapse and conformability within papersheets and tend to produce less opaque sheets, having lower bulk and air permeability, compared to Acacia mangium.

Table 4

Morphological characteristics of Moringa oleifera in comparison with Acacia mangium

\begin{tabular}{lcc}
\hline Particulars & Moringa oleifera & Acacia mangium \\
\hline Fibrous cells & & \\
\hline Minimum fiber length, $\mathrm{mm}$ & 0.35 & 0.22 \\
Maximum fiber length, mm & 3.12 & 2.65 \\
Average fiber length $(\mathrm{L})($ weight weighted), mm & 1.21 & $0.782 \pm 0.001$ \\
Mean fiber width $(\mathrm{D}), \mu \mathrm{m}$ & 15.0 & 16.9 \\
Lumen diameter $(\mathrm{d}), \mu \mathrm{m}$ & 8.78 & $6.77 \pm 0.28$ \\
Cell wall thickness $(\mathrm{w}), \mu \mathrm{m}$ & 3.11 & 3.36 \\
Luce's shape factor, $\left(\mathrm{D}^{2}-\mathrm{d}^{2}\right) /\left(\mathrm{D}^{2}+\mathrm{d}^{2}\right)$ & 0.50 & 0.72 \\
Slenderness ratio $(\mathrm{felting}$ power), $(\mathrm{L} / \mathrm{D})$ & 81.0 & 46.3 \\
Solid factor, $\left(\mathrm{D}^{2}-\mathrm{d}^{2}\right) \times \mathrm{L}$ & 0.179 & 0.188 \\
Runkel ratio, $2 \mathrm{w} / \mathrm{d}$ & 0.71 & 0.993 \\
Flexibility coefficient, $(\mathrm{d} / \mathrm{D}) \times 100$ & 58.5 & 40.1 \\
F factor, $\mathrm{L} / \mathrm{w}$ & 389 & 232.7 \\
Rigidity coefficient, $2 \mathrm{w} / \mathrm{D}$ & 0.415 & 0.398 \\
Fiber curl index $(\mathrm{length}$ weighted) & 5.6 & 0.084 \\
Fiber kink index & 20.6 & 1.66 \\
Total kink angle, degree & 140 & 38.71 \\
Kink per mm & 0.65 & 0.74 \\
\hline Non-fibrous cells & & 228 \\
\hline Length of vessel, $\mu \mathrm{m}$ & 187 & 26.4 \\
Width of vessel, $\mu \mathrm{m}$ & 65 & 93 \\
Length of parenchyma, $\mu \mathrm{mm}$ & 76 & 26.5 \\
Width of parenchyma, $\mu \mathrm{m}$ & 32 & 41.02 \\
Arithmetic fines, $(\mathrm{L}=0.01-0.20 \mathrm{~mm})$ & 26.8 & 6.84 \\
Length weighted fines, $(\mathrm{L}=0.01-0.20 \mathrm{~mm})$ & 4.67 & \\
\hline Stang
\end{tabular}

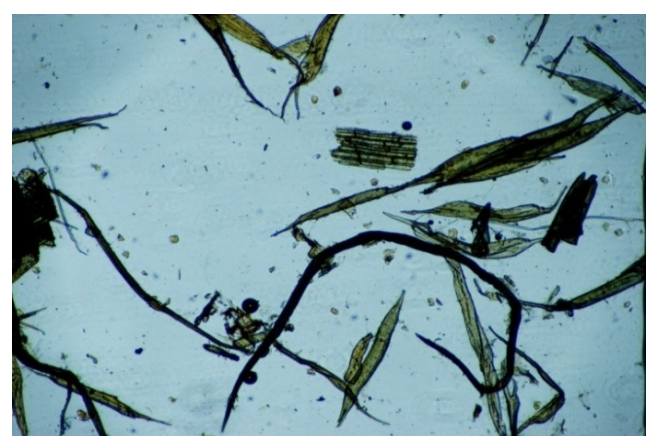

Figure 1: Photomicrographs of unbleached Moringa oleifera fiber at a magnification of $4 \mathrm{x}$

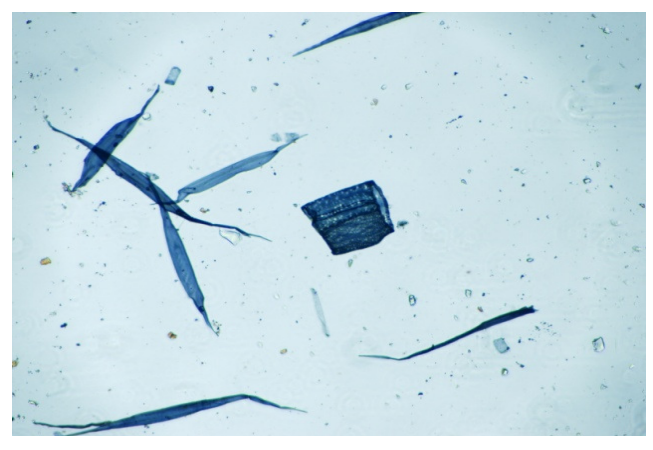

Figure 2: Photomicrographs of bleached Moringa oleifera fiber at a magnification of $4 \mathrm{x}$ 


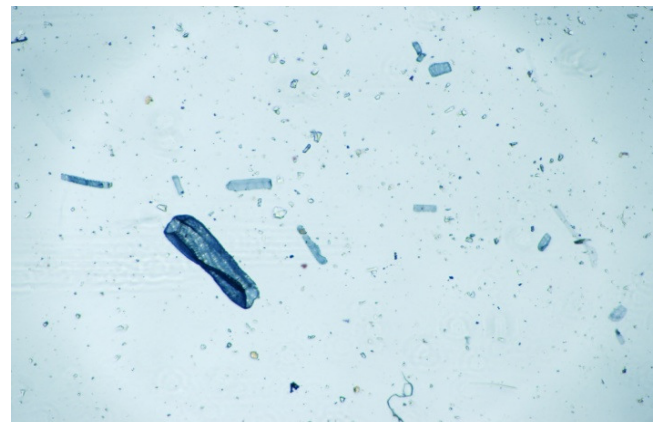

Figure 3: Vessels and parenchyma tissue of Moringa oleifera fiber at a magnification of $4 \mathrm{x}$

The fibers that have a Runkel ratio lower than 1.0 are taken as thin-walled fibers. ${ }^{12}$ On the other hand, the fibers with a Runkel ratio above 1.0 are considered as thick-walled, are stiffer and rigid in nature, forming bulky and less opaque paper, with lower bonded area and are predicted to have good mechanical strength properties. ${ }^{13}$ The Runkel ratio of Moringa oleifera fiber is 0.71 , while Acacia mangium reached 0.99. Luce's shape factor is another important fiber parameter and it is calculated from fiber diameter and lumen diameter. It is directly related to paper sheet density. The value reached for Moringa oleifera fiber is 0.50 , while it is 0.72 in the case of Acacia mangium.

Being thin-walled and highly perforated, the vessel elements are broken into smaller fragments during pulping. If these cells are not well bonded just below the surface of the sheet, then they are picked up in printing. The vessel picking problems are related to vessel width, length, and number per unit weight. ${ }^{14}$ Photomicrographs of the unbleached and bleached pulp fibers were taken by an Olympus BX61 computer aided microscope, at different magnifications. Figures 1 to 4 reveal that a large quantity of parenchyma cells can be observed, which justify the high extractives content of the wood. The fibers are very wide at the center (Fig. 1 and 2). ${ }^{15}$ Some fibers have bifurcations at the ends. Vessels also have peculiar shapes (Fig. 3). Figure 4 shows that the fibers are broad and thin-walled, so they are supposed to easily collapse. ${ }^{16}$ These findings indicate that Moringa oleifera pulp contains cellulose fibers, along with non-fibrous cellular materials, such as parenchyma tissues, vessel elements and epidermal tissues. These nonfibrous cellular materials do not have any paper making properties and adversely affect inter-fiber bonding. The presence of these epidermal cells,

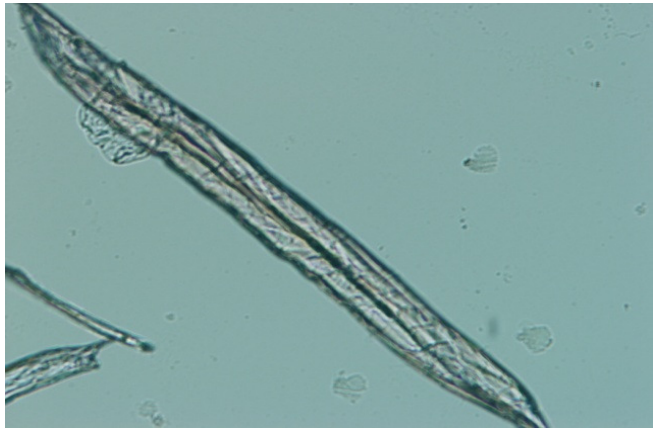

Figure 4: Magnified view of Moringa oleifera fiber at a magnification of $20 \mathrm{x}$

parenchyma tissues and vessel elements explains the high fractions of fines found in the pulp, which are formed during the pulping and pulp beating. Fines are the most undesirable elements in feedstock for paper making, since their presence in the pulp reduces freeness and increases water retention. ${ }^{17}$

\section{Bleaching}

The pulp with kappa number 16.2 was bleached using the DEpD bleaching sequence. An optimized kappa factor of 0.25 was applied in the D stage of bleaching. In Table 5, the results of the DEpD bleaching sequence reveal that the first stage of chlorine dioxide (D) bleaching, a pulp brightness gain was obtained $(51.9 \%)$, while the viscosity decreased by $16.5 \%$. After the DE stages, the pulp brightness increased by $32.95 \%$, whereas kappa number and pulp viscosity decreased $-84.6 \%$ and $12.1 \%$, respectively. The final pulp brightness reached a value of $85 \%$ ISO and pulp viscosity was $530 \mathrm{cc} / \mathrm{g}$.

\section{Bauer McNett classification and physical strength properties}

Table 6 shows the Bauer McNett fiber classification based on the weighted average fiber length. Fiber length is the fundamental property of pulp and its distribution through different mesh sizes $(+30$ to -200$)$ shows the percentage of fiber for each mesh. The +30 fraction is an indication of the presence of coarse fiber in the pulp sample, which is considered as hindrance in paper sheet formation and to smoothness properties, while the +50 and +100 fractions are referred to as useful fibers.

The fiber fraction of +50 is more than $60 \%$, which is suitable for making writing and printing grade paper. The optimal mechanical strength properties were obtained at a refined level of 
freeness of $350 \mathrm{~mL}$ CSF. The results for mechanical strength properties of unbleached and bleached Moringa oleifera pulp in Table 7 reveal that unbleached Moringa oleifera pulp produced a tensile index of $48.7 \mathrm{Nm} / \mathrm{g}$, tear index of 5.8
$\mathrm{mNm}^{2} / \mathrm{g}$, burst index of $3.56 \mathrm{kPam} / \mathrm{g}$ and bulk of $1.25 \mathrm{cc} / \mathrm{g}$, while the bleached pulp reached a tensile index of $45.0 \mathrm{Nm} / \mathrm{g}$, tear index of 5.43 $\mathrm{mNm}^{2} / \mathrm{g}$, burst index of $3.11 \mathrm{kPam}^{2} / \mathrm{g}$ and bulk of $1.21 \mathrm{cc} / \mathrm{g}$, respectively.

Table 5

Bleaching of Moringa oleifera pulp using $\mathrm{D}_{0} \mathrm{EpD}_{1}$ bleaching sequence

\begin{tabular}{lc}
\hline Parameters & Value \\
\hline Unbleached pulp characteristics & \\
\hline Kappa number & 16.2 \\
Brightness, \% (ISO) & 29.5 \\
Viscosity, cc/g & 772 \\
\hline Chlorine dioxide stage $\left(\mathrm{D}_{0}\right)$ & \\
\hline Chlorine dioxide as D, \% & 1.54 \\
Inlet pH & 2.2 \\
Residual chlorine dioxide as D, ppm & 12 \\
Brightness, \% (ISO) & 52.5 \\
Viscosity, cc/g & 645 \\
\hline Extraction peroxide stage (Ep) & 2.5 \\
\hline Kappa number & 78.3 \\
Brightness, \% (ISO) & 567 \\
Viscosity, cc/g & \\
\hline Chlorine dioxide stage (D ${ }_{1}$ ) & 85.0 \\
\hline Final bleached pulp brightness, \% (ISO) & 530 \\
Final bleached pulp viscosity, cc/g & 0.20 \\
Bleached pulp PC number & \\
\hline
\end{tabular}

Table 6

Bauer McNett fiber classification of unbleached and bleached pulps

\begin{tabular}{lccccc}
\hline Sample code & \multicolumn{5}{c}{ \% Fiber fraction retained on different meshes } \\
\hline Fraction & +30 mesh & +50 mesh & +100 mesh & +200 mesh & -200 mesh \\
\hline Unbleached pulp & 10.36 & 12.75 & 30.85 & 24.69 & 21.35 \\
Bleached pulp & 9.1 & 12.93 & 29.17 & 25.38 & 22.42 \\
\hline
\end{tabular}

Table 7

Mechanical strength properties of unbleached and bleached Moringa oleifera pulps

\begin{tabular}{lcccccc}
\hline Parameter & $\begin{array}{c}\text { Rev, } \\
\mathrm{min}\end{array}$ & $\begin{array}{c}\text { Freeness } \\
\mathrm{mL}, \mathrm{CSF}\end{array}$ & $\begin{array}{c}\text { Burst index } \\
\mathrm{KPam}^{2} / \mathrm{gm}\end{array}$ & $\begin{array}{c}\text { Tear index } \\
\mathrm{mNm}^{2} / \mathrm{gm}\end{array}$ & $\begin{array}{c}\text { Tensile index } \\
\text { Nm/gm }\end{array}$ & $\begin{array}{c}\text { Bulk, } \\
\mathrm{cc} / \mathrm{g}\end{array}$ \\
\hline $\begin{array}{l}\text { Unrefined unbleached } \\
\text { Kraft pulp }\end{array}$ & 0 & 560 & 2.69 & 6.0 & 41.3 & 1.34 \\
$\begin{array}{l}\text { Refined unbleached } \\
\text { Kraft pulp }\end{array}$ & 1000 & 376 & 3.56 & 5.8 & 48.7 & 1.25 \\
$\begin{array}{l}\text { Unrefined bleached } \\
\text { Kraft pulp }\end{array}$ & 0 & 545 & 2.24 & 5.77 & 38.9 & 1.30 \\
$\begin{array}{l}\text { Refined bleached } \\
\text { Kraft pulp }\end{array}$ & 1000 & 350 & 3.11 & 5.43 & 45.0 & 1.21 \\
\hline
\end{tabular}

\section{CONCLUSION}

The study investigated the pulp and paper making properties of Moringa oleifera. It has been found that the chemical composition of moringa is similar to that of other hardwoods. The alkali prehydrolysis liquor (PHL) contains high amounts of such elements as calcium (50.9 $\mathrm{mg} / \mathrm{kg})$, potassium $(5140 \mathrm{mg} / \mathrm{kg})$ and iron $(312$ 
$\mathrm{mg} / \mathrm{kg}$ ). The active alkali requirement was $20 \%$ $\mathrm{Na}_{2} \mathrm{O}$ to produce unbleached pulp with a kappa number of 16.2, screened pulp yield of $38.2 \%$ and viscosity $772 \mathrm{cc} / \mathrm{g}$. There were no significant differences in the fiber morphology of the unbleached and bleached Moringa oleifera pulps. The pulp produced was easily bleachable to a brightness of $85 \%$ ISO. The mechanical strength properties of unbleached and bleached Moringa oleifera pulps were at the lower ends of the ranges for hardwood, which implies that pulp from Moringa oleifera can replace hardwood pulp to a low or moderate extent, especially in writing, newspaper, toilet papers etc. Based on the findings, it can be concluded that Moringa oleifera is recommended for utilization in pulp and paper production in wood based paper mills, as its pulping behavior and bleaching response are similar to those of other hardwoods. The fast growth of Moringa oleifera and the multiple end uses of various parts of the plant support its mass plantation through farm forestry or social forestry programs, which will help farmers in many ways.

\section{REFERENCES}

1 Deepika, K. Anupam, V. Swaroop and P. S. Lal, Int. J. Sci. Res., 8, $613 \quad$ (2019), https://doi.org/10.21275/ART20195143

2 J. B. Benitez, M. E. Vallejos, M. C. Area and F. E. Felissia, RECyT, 20, $48 \quad$ (2018), https://www.researchgate.net/publication/329217133

3 V. Sharma, R. Paliwal and S. Sharma, J. Pharm. Res., 4, 554 (2011), http://jprsolutions.info

4 C. Ramachandran, K. V. Peter and P. K. Gopalakrishna, Indian Veg. Econ. Bot., 34, 276 (1980), https://doi.org/10.1007/BF02858648

5 J. A. Parrotta, Int. Inst. Trop. For., 61, 7 (1993)
6 T. P. Mall and S. C. Tripathi, Int. J. Curr. Res. Biosci. Plant Biol., 4, $52 \quad$ (2017), https://doi.org/10.20546/ijcrbp.2017.408.008

7 M. L. Price and K. Davis, The Moringa Tree, 2000, http://www.pkdiet.com/pdf/food/drumstick/Moringa1. PDF

8 J. A. Parrotta, U.S. Department of Agriculture, Forest Service, Southern Forest Experiment Station, 1993, pp. 1-6

9 A. K. Sharma, D. Dutt, J. S. Upadhyaya and T. K. Roy, BioResources, 6, $5062 \quad$ (2011) https://bioresources.cnr.ncsu.edu/BioRes_06/BioRes_0 6_4_5062_Sharma_DUR_Anatom_Morph_Chem_Ba musa_Eucalyptus_2140.pdf

10 S. D. Arora, J. G. Onsare and H. J. Kaur, Pharmacog. Phytochem., 1, 193 (2013), www.phytojournal.com

11 H. Kirci, "Pulping Industry", KTU Faculty of Forest Press, No. 86, Trabzon, 2006

12 I. Jusoh, F. A. Zaharin and N. S. Adam, BioResources, $\quad 9, \quad 150 \quad$ (2014), https://bioresources.cnr.ncsu.edu/wpcontent/uploads/2016/06/BioRes_09_1_150_Jusoh_wo od_Quality_Acacia_Hybrid_4610.pdf

13 A. K. Sharma, K. Anupam, V. Swaroop and V. Bist, J. Clean. Prod., 3, 95 (2014), https://doi.org/10.1016/ j.jclepro.2014.03.095

14 H. Kaur and D. Dutt, Cellulose Chem. Technol., 47, 83 (2013), https://www.cellulosechemtechnol.ro/pdf/ CCT1-2(2013)/p.83-94.pdf

15 O. T. Khider and O. T. Elsaki, J. Forest Prod. Ind., 1, 5 (2012)

16 M. Sharma, C. L. Sharma and B. Y. Kumar, Res. J. Agric. For. Sci., 1, $15 \quad$ (2013) https://www.isca.in/AGRI_FORESTRY/Archive/v1/i3 3.ISCA-RJAFS-2013-017.pdf

17 O. L. M. Kamoga, J. B. Kirabira, J. K. Byaruhanga, R. D. Godiyal and K. Anupam, Cellulose Chem. Technol., 50, $275 \quad$ (2016), $\quad$ https:// www.cellulosechemtechnol.ro/pdf/

CCT2(2016)/p.275-284.pdf 